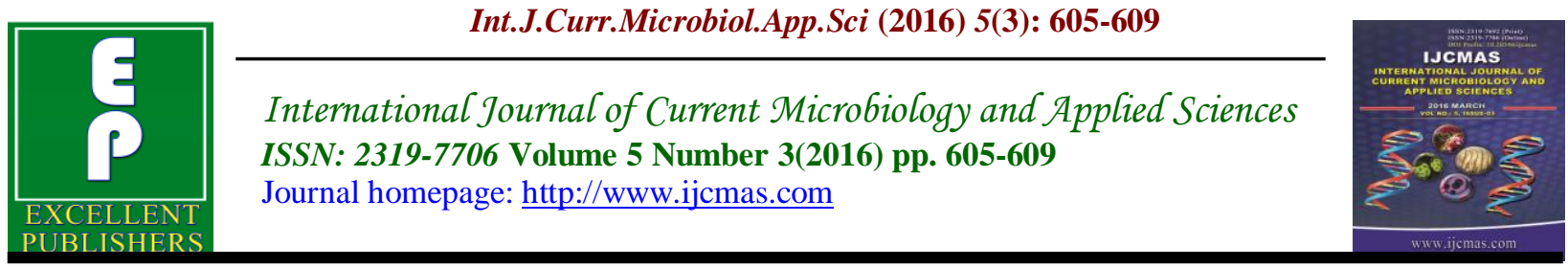

Original Research Article

http://dx.doi.org/10.20546/ijcmas.2016.503.070

\title{
Significance of Modified Widal Test with Conventional Widal Test in the Diagnosis of Enteric Fever
}

\author{
K. Sendil kumar, R. Prakash*, S. A. Lakshminarayana and S. Sangeetha \\ Department of Microbiology, Rajarajeswari Medical College \& Hospital, \#202, \\ Kambipura, Mysore road, Bangalore-74 \\ *Corresponding author
}

\begin{tabular}{|c|c|}
\hline & A B S T R A C T \\
\hline $\begin{array}{l}\text { Enteric fever, } \\
\text { Salmonella typhi, } \\
\text { Salmonella } \\
\text { paratyphi, } \\
\text { Modified Widal } \\
\text { test, } \\
\text { Conventional } \\
\text { Widal test. }\end{array}$ & \multirow{3}{*}{$\begin{array}{l}\text { Enteric fever is a systemic infection caused by Salmonella serotypes; } S \text {. typhi, } S \text {. } \\
\text { paratyphi A, } S \text {. paratyphi B, } S \text {. paratyphi C and } S \text {. sendai. Worldwide over } 2.16 \\
\text { million cases and } 216000 \text { deaths and } 90 \% \text { of these cases and deaths have resulted } \\
\text { in Asia in the year } 2000 \text {. Rising titre in conventional Widal test is the commonly } \\
\text { used test for diagnosis of enteric fever. To compare conventional tube Widal test } \\
\text { with the modified tube Widal test in the diagnosis of recent and old enteric fever. } \\
\text { Fifty samples each were collected aseptically from positive slide Widal } \\
\text { agglutination test and normal healthy individuals. Serum separated was used for } \\
\text { both the conventional and modified tube Widal test. The modified tube Widal test } \\
\text { was done using mercaptoethanol method. In conventional Widal test, majority of } \\
\text { the patients showed a titre of antibodies for 'O' antigens from } 1: 160(56 \%) \text { to } \\
1: 320(30 \%) \text { and for H antigens from } 1: 160(38 \%) \text { to } 1: 320(48 \%) \text {. Titres after } \\
\text { treatment of serum samples with } 2-\text { Mercaptoethanol showed a significant fall in } \\
\text { titre of } 1: 40(\%) \text { followed by } 1: 80(\%) \text { for O and H antigens respectively. A single } \\
\text { test of conventional Widal test combined with modified Widal test is sufficient to } \\
\text { differentiate recent and old enteric fever. }\end{array}$} \\
\hline Article Info & \\
\hline & \\
\hline
\end{tabular}

\section{Introduction}

Enteric fever is a systemic infection caused by Salmonella serotypes; $S$. typhi, $S$. paratyphi A, S. paratyphi B, S. paratyphi Cand S. sendai (Mandell GL et al, Parker MT). It is characterized by malaise, fever, abdominal discomfort, transient rash, splenomegaly, hepatomegaly, bradycardia, and leucopenia. Major complications are intestinal hemorrhage and perforation (Hook EW et al). It is still an important public health problem in developing countries. Worldwide over 2.16 million cases and
216000 deaths have resulted due to typhoid. Among them $90 \%$ of these cases and deaths have resulted in Asia in the year 2000. (Crump JA et al)

Isolation of the organism from bone marrow $(85-95 \%)$, blood $(70 \%)$ and stool $(45-65 \%)$ is currently considered the most reliable diagnostic method. (Gilman RH et al) As culture facilities are not available in all the hospitals, diagnosis will be usually based on the clinical findings along with Widal test. 
The commonly used Widal test is an tube agglutination test for the $\mathrm{O}$ and $\mathrm{H}$ antigens of $S$. typhi, and $\mathrm{H}$ antigens of $S$. paratyphi A and $S$. paratyphi B, which should show an significant rise in titre subsequently. (Senewiratane B et al, Editorial Br. Med J 1978:1:389) Negative Widal test is considered as reliable than the positive one and the information provided by the test is not adequate as the titre may be due to nonspecific causes (Pai et al).

So the four fold rise in titre with paired sera taken 4 to 5 days apart is considered as more reliable for the diagnosis of enteric fever. (Editorial Br. Med J 1978:1:389) This is rarely done as the patient will be treated with the report of a single Widal test. So the need for the modification of Widal test was considered using 2-mercaptoethanol (2$\mathrm{ME}$ )in order to improve the diagnostic capability. 2-mercaptoethanol easily denatures the IgM class of antibodies, so if a decrease in the titer is seen after using this agent, it means that the contribution of $\operatorname{IgM}$ has been removed leaving the $\mathrm{IgG}$ component. This differentiation of antibody classes is important; as it allows for the distinction of a recent from an old infection. (Widal test. elearning.uokerbala.edu.iq)

Hence this study was done to differentiate the recent infection from the old infection to give an adequate information with a single Widal test titre to the clinicians for treating the disease earlier.

\section{Materials and Methods}

This study was conducted in the department of microbiology of Rajarajeswari Medical College and Hospital over a period of 6 months. Ethical committee clearance was taken from our institutional ethical committee. Fifty serum samples were selected as the test group for the conventional and modified tube agglutination test which were positive in slide agglutination test. Fifty normal healthy individuals with no history of any fever or immunization against typhoid and paratyphoid fever were selected as controls.

Samples were collected aseptically and serum was separated for both the conventional and modified tube Widal test.

\section{Conventional Widal Test}

This test was performed by using the commercially available antigen from span diagnostics ltd by Tube agglutination method.

Serial dilutions of patient serum for somatic antigens of Salmonella typhi (TO) and flagellar antigens of Samlonella typhi $(\mathrm{TH})$, Salmonella paratyphi A (AH) and Salmonella paratyphi B (BH) from 1:20 to 1:640 was prepared. The tubes were incubated overnight at $37^{\circ} \mathrm{C}$. Reading were taken in comparison with the controls. The tube with highest dilution showing agglutination was taken as titre of the serum (Ananthanarayan R, Panikar CKJ, Myers and Koshis).

\section{Modified Widal Test}

This test was done using mercaptoethanol method. (Cruickshank $\mathrm{R}$ et al) Eight serial dilutions of serum from 1:20 to 1: 640 was done using $0.05 \mathrm{M}$ 2-Mercaptoethanol solution in normal saline. The serum was kept in the water bath at $37^{\circ} \mathrm{C}$ for 15 mins. The rest of the procedure was done as in the conventional Widal test.

\section{Statistical Analysis}

The data was analyzed using percentile. 


\section{Results and Discussion}

A total of 50 serum samples from control subjects and 50 serum samples from the known slide Widal test positive cases were taken over a period of 6 months for this study. The age ranged from 3 to 60 years with a mean of 27 years. Male: female ratio was 1: 0.95 in this study. The control group of serum samples showed a baseline titres of 1:40 for somatic antigens of Salmonella typhi (TO) and flagellar antigens of Samlonella typhi (TH), Salmonella paratyphi A (AH) and Salmonella paratyphi $\mathrm{B}(\mathrm{BH})$ except in four samples where the baseline titres were 1:80 in both conventional and modified Widal test.

The titres by conventional tube Widal test for the ' $\mathrm{O}$ ' and ' $\mathrm{H}$ ' antigens are shown in the table 1 .

Majority of the patients showed a titre of antibodies for ' $\mathrm{O}$ ' antigens from 1:160 (56 $\%)$ to $1: 320(30 \%)$ and for $\mathrm{H}$ antigens from $1: 160(38 \%)$ to $1: 320(48 \%)$. Only two patients $(4 \%)$ showed 1:80 titres for $\mathrm{O}$ antigens and seven patients (14\%) showed titres of 1:640 for $\mathrm{H}$ antigens. The titres by Modified tube Widal test for the ' $\mathrm{O}$ ' and ' $\mathrm{H}$ ' antigens are shown in the table 2.

Table.1 Conventional Tube Widal Test Titres

\begin{tabular}{|l|c|c|c|c|c|c|}
\hline \multirow{2}{*}{ Antigens } & \multicolumn{7}{|c|}{ Titres of Antibodies } \\
\cline { 2 - 7 } & $\mathbf{1 : 2 0}$ & $\mathbf{1 : 4 0}$ & $\mathbf{1 : 8 0}$ & $\mathbf{1 : 1 6 0}$ & $\mathbf{1 : 3 2 0}$ & $\geq \mathbf{1 : 6 4 0}$ \\
\hline O (S. typhi) & 0 & 0 & 2 & 28 & 15 & 5 \\
\hline H (S. typhi) & 0 & 0 & 0 & 19 & 24 & 7 \\
\hline
\end{tabular}

Table.2 Modified Tube Widal Test Titres

\begin{tabular}{|l|c|c|c|c|c|c|}
\hline \multirow{2}{*}{ Antigens } & \multicolumn{7}{|c|}{ Titres of Antibodies } \\
\cline { 2 - 7 } & $\mathbf{1 : 2 0}$ & $\mathbf{1 : 4 0}$ & $\mathbf{1 : 8 0}$ & $\mathbf{1 : 1 6 0}$ & $\mathbf{1 : 3 2 0}$ & $\geq \mathbf{1 : 6 4 0}$ \\
\hline O (S. typhi) & 0 & 45 & 5 & 0 & 0 & 0 \\
\hline H (S. typhi) & 0 & 32 & 14 & 4 & 0 & 0 \\
\hline
\end{tabular}

After treatment of serum samples with 2Mercaptoethanol showed a significant decrease in titre for both $\mathrm{O}$ and $\mathrm{H}$ antigens. A titre of 1:40 and 1:80 were $90 \%$ and $10 \%$ for $\mathrm{O}$ antigens and $64 \%$ and $28 \%$ for $\mathrm{H}$ antigens respectively.

The serum samples of test group did not show any difference in titres for both the conventional and modified Widal test. There was no difference in titres for the $S$. paratyphi A and S. paratyphi B antigens in clinically suspected enteric cases and normal individuals by both the conventional and modified Widal test in our study.
The Widal agglutination test which was developed by F Widal in 1896 is the commonest test used for the diagnosis of enteric fever for more than 100 years. (Widal FM, Parry CM et al ) O (predominantly $\mathrm{IgM}$ ) and $\mathrm{H}$ (IgG andIgM) agglutinating antibodies are used in this test to detect the enteric fever. The value of a single Widal test has been still in debate while four fold rise in antibody titre has been of some significance in the diagnosis of enteric fever (Ananthanarayan R, Panikar CKJ, Sharma I et al).

It's not always possible to wait till the rise in 
titre and the rise in titre can be due to nonsalmonella infections and hyperglobulinaemic conditions as well (kumar et al) have showed that the IgM antibody is raised in the first three weeks which is inactivated by $2-\mathrm{ME}$ and $\mathrm{IgG}$ antibody raises after 3 weeks of infection due to Salmonella. These antibodies are also seen in high levels in people from developing countries.

Adopting the method of inactivating $\operatorname{IgM}$ using 2-ME and determining the fall in titre of $\operatorname{IgM}$ antibodies was done in this study. There was a 4 fold decrease in $\mathrm{O}$ and $\mathrm{H}$ antibodies in our study whereas there was no difference in titre in control subjects. A study conducted by Pai $\mathrm{AP}^{8}$ using 50 bacteriologically positive cases of Salmonellatyphi infection and 50 healthy individuals showed the same results as our study. Rao BN et al has also reported that there was a 4 fold difference in the titre in the modified Widal test from 50 cases in the test group. Ratan et al has shown the same results as the other authors in 25 cases of test and control group.

Limitations of our study: 1) Sample size of our study was small which can be improved by increasing the number of patients and 2) Correlation with blood culture was not done in our study.

In conclusion, simultaneous use of modified Widal test and conventional Widal test on a single serum sample will lead to early diagnosis of enteric fever with the distinction of early and late stage of enteric fever. The modified Widal test can also decrease the false positive results.

\section{References}

Ananthanarayan R, Panikar CKJ. Textbook of Microbiology, $7^{\text {th }}$ ed. Orient Longman Ltd. 84, 2000; pp no 297-99.
Cruickshank R, Duguid JP, Marmicer BP, Swain RHA. Medical Microbiology, $12^{\text {th }}$ ed. Edinburgh, Churchill Livingstone, 1975;2:454-61.

Crump JA, Luby SP, Mintz ED. The global burden of typhoid fever. Bull World Health Organ 2004; 82: 346-53.

Editorial: Typhoid and its serology. Br Med J 1978; 1:389.

Gilman RH, Terminel M, Levine MM, Hernandez-Mendoza P, Hornick RB. Relative efficacy of blood, urine, rectal swabs, bone marrow, and rosespot cultures for recovery of Salmonella typhiin typhoid fever. Lancet 1975; 1: 1211-13.

Hook EW, Gurrant RL.Salmonella infection: Harrison's Principles of Internal Medicine, 11th ed., McGraw Hill, KogaKusha Ltd., international student edition, 1987.

Kumar R, Malaviya AN, Murthy RGS, Venkataraman M, Mohapatra LN. Immunological study of typhoid: Immunoglobulins, C3, Antibodies, and Leukocyte Migration Inhibition in patients with typhoid fever and TABvaccinated individuals. Infect Immun 1974; 10(6):1219-25.

Mandell GL, Bennett JE, Dolin R. Enteric fever and other causes of abdominal symptoms with fever; principle and practice of infectious diseases; $6^{\text {th }}$ ed; volume $1 ; 1273$.

Myer's and Koshi's; Manual of Diagnostic Procedures in medical microbiology and Immunology/ serology Christian Medical College and Hospital, Vellore, India; 139.

Pai AP, Koppikar GV, Deshpande S. Role of modified Widal test in the diagnosis of enteric fever. J Assoc Physician India 2003;51:9-11.

Parker MT. Enteric Infection; Typhoid and Paratyphoid, editors Parker MT, Collin LH, Edward Arnold, In: Topley 
and Wilson's principles of bacteriology, Virology and Immunology: Arnold London; 1990; vol 3: $8^{\text {th }}$ edn, 424-46.

Parry CM, Hoa NT, Diep TS, Wain J, Chinh NT, Vinh H, et al. Value of a singletube Widal test in diagnosis of Typhoid Fever in Vietnam. J ClinMicrobiol1999; 37: 2882-86.

Rao BN. An evaluation of modified Widal test in the diagnosis of enteric fever. $\mathbf{J}$ Indian Med Assoc 1989; 87(8):179-80.

Ratan A, Maheshwari V, Maheshwar NK, Malik A, Malik MA. Application of modified Widal test in specific diagnosis of enteric fever. Indian Pediatr 1990; 27:295-97.
Senewiratane B,Chir B, Senewiratane K. Reassessment of Widal test in the diagnosis of typhoid fever. Gastroenterology 1977; 73: 233-236.

Sharma I, Devi TL, Sen SS. Significance of widal test in diagnosis of typhoid fever in Assam, India. World $\mathrm{J}$ Pharm PharmaceuSci 2014; 3(3):1719-24.

Widal FM.Serodiagnostic de la fiévretyphoide a-propos d'uve modification par MMC Nicolle et al. Halipie. Bull Soc Med Hop Paris 1896; 13:561-66.

Widal test. elearning. uokerbala.edu.iq $/ \mathrm{mod} / \mathrm{resource} / \mathrm{view}$. php?id=2877.

\section{How to cite this article:}

Sendil kumar, K., R. Prakash, S. A. Lakshminarayana and Sangeetha, S. 2016. Significance of Modified Widal Test with Conventional Widal Test in the Diagnosis of Enteric Fever. Int.J.Curr.Microbiol.App.Sci. 5(3): 605-609. doi: http://dx.doi.org/10.20546/ijcmas.2016.503.070 